Reviews in Digital Humanities

\title{
Review: Slave Revolt in \\ Jamaica, 1760-1761: A \\ Cartographic Narrative
}

\section{Ethan Warren ${ }^{1}$}

${ }^{1}$ University of Texas at Austin

Published on: Feb 08, 2021

License: Creative Commons Attribution 4.0 International License (CC-BY 4.0). 


\section{Project}

Slave Revolt in Jamaica, 1760-1761: A Cartographic Narrative

Project Director

Vincent Brown, Harvard University

\section{Project URL}

http://revolt.axismaps.com/

\section{Project Reviewer}

Ethan Warren, University of Texas at Austin

\section{Project Overview}

\section{Evan Miller}

Slave Revolt in Jamaica, 1760-1761: A Cartographic Narrative is dedicated to examining the "spatial history of the greatest slave insurrection in the eighteenth-century British Empire" (Brown 176). Along with a cursory summary of the key events - the initial slave rebellion, the British Military suppression, the subsequent deaths and banishments - there are four main features of this project: the base maps, the locational database, the symbol design, and the interface. These interactive features serve to offer a spatial understanding of the timeline of events of the revolt, with a goal of gaining further understanding of how the topography of the landscape affected the tactics and strategies of the insurrection and counterinsurgencies through cartographic inspection. Vincent Brown, Charles Warren Professor of American History and African and African-American at Harvard University, is the principal investigator and curator of this project. His principal collaborators were David Heyman, Ben Sheesley, and Andy Woodruff at Axis Maps.

Beginning as a heuristic tool to conduct research on the otherwise under-studied Jamaican revolt generally called "Tacky's Revolt" - this project started as a timeline of events to assist in answering the "elementary historical questions" surrounding the revolt (Brown 179). From this initial use of contemporary media tools, the project - the website and digital sources - was born. Its primary maps - the base map and the thematic map - are derived from a combination of eighteenth-century maps, along with various textual sources: Edward Long's and Bryan Edwards' historical accounts, supplemented with periodicals, diaries, private correspondences, and military and administrative records documenting the events of the revolt and counterinsurgencies. These two maps provide the basis for the symbol design, as well as the interface, an interactive feature stemming from the maps that allows the viewer to navigate the timeline of events. 
This project is designed to be accessible and interpreted by a wide audience that includes academic scholars, students, and laypeople who possess an interest in Jamaican history, British colonialism, and/or cartography. The summary and interactive features offer a comprehensive overview of the events and related scholarship and can be understood by those without extensive knowledge of the historical context. However, for scholars or those with deeper understanding, this project offers a spatial-temporal view into the most salient aspects of the insurrection.

This project was supported by a Mellon New Directions Fellowship, the National Humanities Center, Duke University, and Harvard University. Brown also attributes his interest in spatial reasoning to the Counter-Mapping Workshop at the University of North Carolina at Chapel Hill in 2011-2012, the staff at Harvard University Center for Geographic Analysis, Stanford University's Spatial History Project, participants of the Atlantic Geographies Seminar held at University of Miami in 2014-15, and members of Axis Maps. The project was given a favorable review by Natalie A. Zacek in The American Historical Review in 2016, who, in exploring the benefits of digital scholarship, writes, "It is essential reading not only for historians...but for anyone who would like to learn more about how digital tools can contribute to the humanities" (175). In his article detailing the creation of his project, Brown also notes the posting of the project from a Reddit page to a fan-site of Joe Rogan, resulting in over 33,000 visitors to the site in a 24-hour span, extending the site's reach to 139 countries and 5,600 cities around the world.

Works Cited

Brown, Vincent. "Narrative Interface for New Media History: Slave Revolt in Jamaica, 1760-1761." The American Historical Review, Vol. 121, No. 1, 2016, pp. 176-186. https://doi.org/10.1093/ahr/121.1.176.

Zacek, Natalie A. "Reading the Rebels and Mining the Maps: Digital Humanities and Cartographic Narratives." The American Historical Review, Vol. 121, No. 1, 2016, pp. 167-

175. https://doi.org/10.1093/ahr/121.1.167.

\section{Project Review}

\section{Ethan Warren}

Developed by historian Vincent Brown, Slave Revolt in Jamaica, 1760-1761: A Cartographic Narrative presents an animated, thematic map of the largest enslaved insurrection in the 18th-century British Empire. As a "cartographic narrative," Slave Revolt in Jamaica, 1760-1761 explores fundamental historical questions: "Was the revolt a unified and coordinated affair, or was it instead a series of opportunistic riots? What in fact did the rebels hope to achieve? Was there ever a real danger to the British Empire in America or was the threat blown out of proportion by panicked whites? If the insurrection was as well planned as the colonists feared, why didn't it succeed?" 
The underlying dataset includes maps produced by the British Empire, diaries, private correspondence, periodicals, military and administrative records, and selected secondary sources that document the roughly 1500 enslaved people who staged a revolt against colonial rule. The project uses cartographic analysis of the revolt to shed light on material that textual sources cannot, such as military tactics and the importance of physical terrain. As the project notes, this map is an argument - an attempt to illustrate potential reasons or strategies for the rebels' actions and the tactics of counterinsurgency. This cartographic analysis is a welcome addition to digital humanities scholarship as it both suggests how historians must read against textual bias as well as the merits of cartography as a method of analysis. Brown is to be commended for his project description page, which includes a methodological exposition of the historical evidence and the maps. He also highlights uncertainty within the dataset where evidence is missing.

Brown, along with the team at Axis Maps, articulate a clear method of how mapping functions to answer the questions framing the project. They used Leaflet, a free JavaScript library for mapping that allows users to build a map that is mobile-application friendly. The map identifies the path of the rebels and the insurrection as a whole, showing both natural terrain and human-made landscapes. Time lapse via mouse-clicks or the play function allows users to visualize the revolt both spatially and temporally as they see where and when the rebels clash with different factions of the British army. Slave Revolt in Jamaica, 1760-1761 is cognizant of, and honest about, potential shortcomings of cartographic analysis, including the issues of perspective and scale when trying to capture individual actions.

Slave Revolt in Jamaica, 1760-1761 is a fascinating piece of scholarship as it successfully charts out the path of the insurrection. Users can easily understand both the size of the uprising and its multifaceted nature with uprisings launched and quelled in several different cities at different times. The project thus subverts the historical interpretations laid out by earlier scholars like Edward Long. The project would benefit from more information on previous historical accounts, including Long's, to more clearly identify for the non-specialist exactly how innovative Brown's conclusions are. Similarly, Brown might consider publishing the underlying dataset to enable other researchers working in the field to reuse and build on the work he's already completed. This would be particularly useful to other digital humanists working on revolts, insurrections, and other uprisings in the same period. Digitized document readers would be a preliminary step towards more exhaustive efforts. Future work might also include pedagogical materials that could help teachers utilize the project in classrooms. 